Viewpoints

\title{
Revisiting the Stress Concept: Implications for Affective Disorders
}

\author{
Bruce S. McEwen ${ }^{1}$ and Huda Akil ${ }^{2}$ \\ ${ }^{1}$ The Rockefeller University, New York, New York 10065, and 2University of Michigan Medical School, Ann Arbor, Michigan 48109
}

Over the last 50 years, the concept of stress has evolved significantly, and our understanding of the underlying neurobiology has expanded dramatically. Rather than consider stress biology to be relevant only under unusual and threatening conditions, we conceive of it as an ongoing, adaptive process of assessing the environment, coping with it, and enabling the individual to anticipate and deal with future challenges. Though much remains to be discovered, the fundamental neurocircuitry that underlies these processes has been broadly delineated, key molecular players have been identified, and the impact of this system on neuroplasticity has been well established. More recently, we have come to appreciate the critical interaction between the brain and the rest of the body as it pertains to stress responsiveness. Importantly, this system can become overloaded due to ongoing environmental demands on the individual, be they physical, physiological, or psychosocial. The impact of this overload is deleterious to brain health, and it results in vulnerability to a range of brain disorders, including major depression and cognitive deficits. Thus, stress biology is one of the best understood systems in affective neuroscience and is an ideal target for addressing the pathophysiology of many brain-related diseases. The story we present began with the discovery of glucocorticoid receptors in hippocampus and has extended to other brain regions in both animal models and the human brain with the further discovery of structural and functional adaptive plasticity in response to stressful and other experiences.

\section{Introduction}

The concept of stress permeates our culture at multiple levels. In normal parlance, it indicates a demanding, sometimes overwhelming, state, accompanied with negative emotions. For many scientists, the word stress is associated with Selye's characterization of a "fight-or-flight" response to a threat, that is, an acute, adaptive response to an environmental stimulus. But over the last 50 years, science in general and neuroscience in particular have expanded these ideas along many dimensions. We conceive of biological responses to stress biology not in terms of engendering a negative state, but as a typically positive, adaptive set of mechanisms that enhance survival. As importantly, we have come to appreciate that stress biology is not simply an "emergency system," but rather an ongoing process: the body and brain adapt to our daily experiences whether we call them stressful or not. These experiences include our adherence or lack thereof to our circadian cycle, whether we are lonely or socially interactive, our daily physical activity, and whether we live in a crowded, noisy, dangerous environment or have access to green space and some sources of peace and tranquility. Given this, we recognize that chronic, uncontrollable stress is not only negative, but can become toxic,

\footnotetext{
Received April 1, 2019; revised Nov. 24, 2019; accepted Nov. 29, 2019.

Recent research referred to in this report was supported by National Institutes of Health (NIH) Grant R01MH41256 (to B.S.M.); The Hope for Depression Research Foundation (B.S.M., H.A.); NIH/National Institute on Drug Abuse Grant U01-DA-043098 (to H.A.); NIH/National Institute of Mental Health Grant R01-MH-104261 (to H.A.); Office of Naval Research Grants N00014-12-1-0366 and 00014-19-1-2149 (to H.A.); and the Pritzker Neuropsychiatric Research Consortium (H.A.).

The authors declare no competing financial interests.

Correspondence should be addressed to Huda Akil at akil@umich.edu.

https://doi.org/10.1523/JNEUROSCI.0733-19.2019

Copyright $\odot 2020$ the authors
}

harming physical and psychiatric health. Thus, we have come to differentiate "good stress" and "bad stress" (McEwen, 2019; Spencer-Segal and Akil, 2019).

This view of the biology of stress has led to the concept of allostasis and allostatic load/overload (Fig. 1). Allostasis refers to the active process of adapting and maintaining stability (or homeostasis) through the production of mediators, like cortisol, that promote adaptation. However, if the perturbations in the environment are unrelenting, the equilibrium set point needs to be altered to a "new normal," and this can be costly to the organism. "Allostatic load refers to the price the body pays for being forced to adapt to adverse psychosocial or physical situations" (McEwen, 2000). These concepts highlight the protective effects of the multiple, nonlinear mediators of adaptation, as well as the damage that occurs when the same mediators are overused or dysregulated.

This broad and evolving concept of stress biology places the brain at the center of the response to experience, as it integrates information about the internal and external environment and shapes responses at both the systemic and behavioral levels (McEwen, 1998). The brain is a vulnerable organ that can be damaged by toxic stress, but it is also capable of adaptive plasticity and resilience. This plasticity exists throughout life, with critical periods such as early life and adolescence when it is particularly evident. The neural adaptations to the environment are cumulative across the life span, and brain function at any later point in life is the result of experiences and epigenetic alterations that take place before conception, during gestation, and throughout postnatal development.

This reconceptualization of stress is also informed by an impressive body of knowledge about its biological underpinnings at 

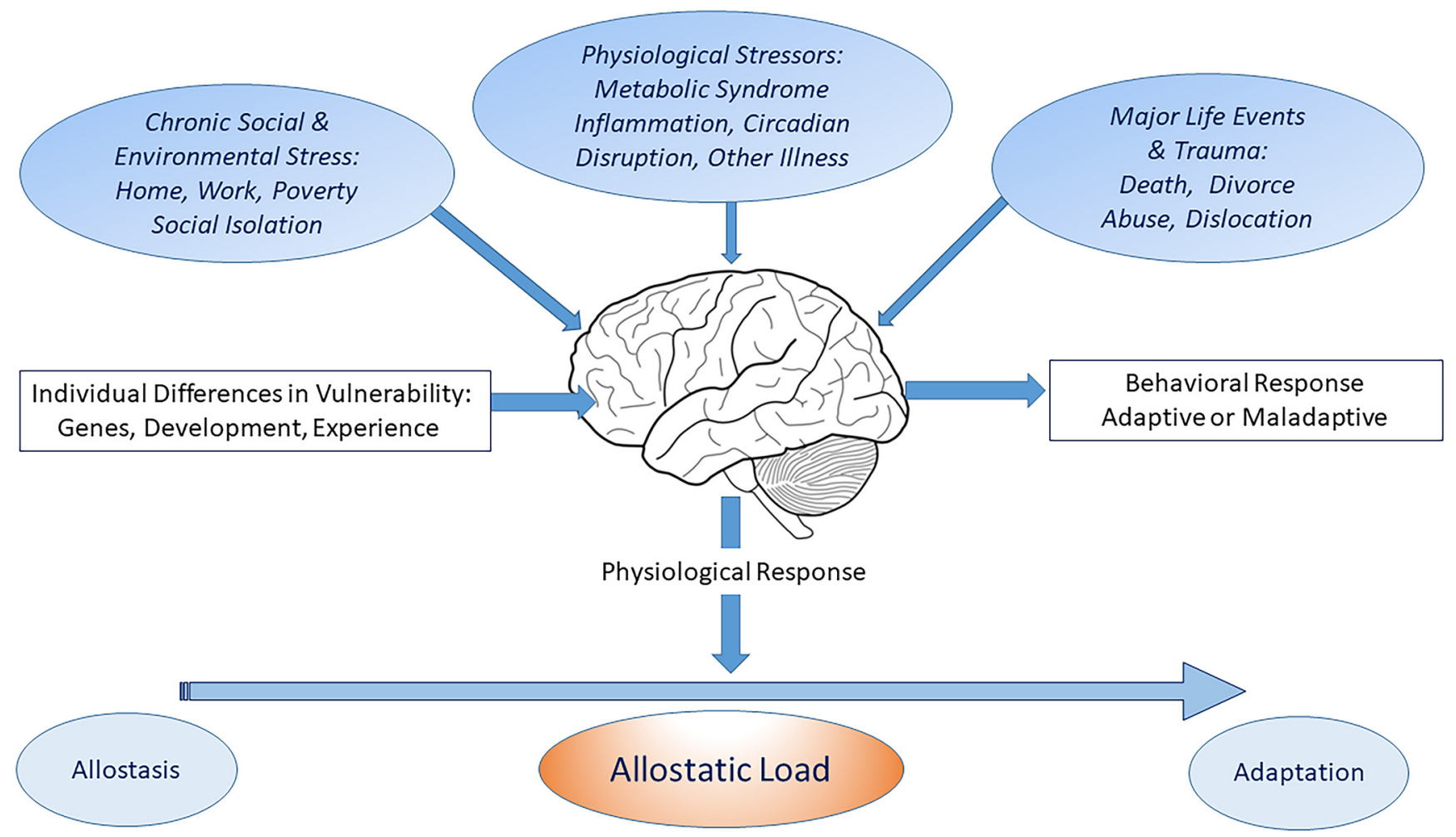

Figure 1. The brain is a primary organ that perceives and responds to what is stressful to an individual. The major function of cortisol and other mediators of allostasis is to promote adaptation. However, overuse and/or dysregulation among the mediators of allostasis lead to allostatic load (or overload) and accelerate disease processes such as cardiovascular disease, diabetes, and affective disorders. Three limbic brain regions are noted.

the molecular, circuit, and endocrine levels. The landmark discoveries of key molecular players coupled with the characterization of underlying neural circuitry provide an exciting framework for understanding a basic, shared function in all organisms as they cope and adapt to their environment. As importantly, since psychiatric, addictive, and many neurological disorders are often triggered or aggravated by life stressors, stress biology represents a springboard for translational research across the range of brain disorders.

In this article, we summarize what we believe are the key ideas and findings that have helped to shape the field of stress neurobiology over the past 50 years. While the review is not intended to be exhaustive, we fully recognize numerous and critical contributions by other laboratories, many of whom are referenced in text or tables.

\section{The major neural and molecular elements of the stress system}

The cascade of events that leads to an adaptive stress response is well delineated (Fig. 2). Acutely, a novel, unexpected, or threatening stimulus, either within the organism or in its environment, triggers neural responses in the brain that are appropriate to that stimulus (e.g., in the auditory system if it was a loud noise). Beyond the sensory encoding is an affective response that labels the stimulus as salient, relevant, sometimes positive, and sometimes threatening. The final common path for this affective response leads to the paraventricular nucleus of the hypothalamus $(\mathrm{PVN})$, where it activates the release of corticotropin-releasing factor [CRF; or corticotropin-releasing hormone (CRH)] as well as arginine vasopressin. These neuropeptides then stimulate the release of adrenocorticotropic hormone (ACTH) from the anterior pituitary, leading to the synthesis and release of glucocorti- coids from the adrenal cortex. These glucocorticoids have a wide range of actions throughout the body (including energy balance and glucose utilization, as indicated by their name).

Fifty years ago, around the time of the founding of the Society for Neuroscience, the concept of a hypothalamo-pituitary-adrenal (HPA) axis existed in neuroendocrinology, but the emphasis was on the role of putative releasing factors in the hypothalamus with little focus on other brain areas. There had been a longstanding quest for a molecular understanding of all the key players in the stress axis. Pioneering work by (Li et al., 1942, 1955) led to the isolation of ACTH from the pituitary gland (Turecki and Meaney, 2016). By the 1970s, elegant biochemical work showed that ACTH derived from a complex molecular precursor, which encoded not only ACTH, but also the opioid $\beta$-endorphin and $\alpha$ and $\beta$-melanocyte stimulating hormone (Mains et al., 1977; Roberts and Herbert, 1977). Forty years ago, the full ACTH/ endorphin precursor was cloned and came to be known as proopiomelancortin (POMC; Nakanishi et al., 1979). POMC undergoes ordered post-translational processing in the anterior pituitary to release the stress hormone ACTH into the bloodstream along with $\beta$-lipotropin. POMC was the first gene whose expression was demonstrated in the brain using in situ hybridization (Gee et al., 1983). It was clear even then that brain POMC serves functions distinct from pituitary POMC (Akil et al., 1984). The hypothalamic factors that release ACTH from the anterior pituitary were also the subject of an intense search. While evidence of various activities emerged in the 1960s (Schally et al., 1960), it was not till 1981 that Vale et al. (1981) isolated CRF and demonstrated that it releases ACTH.

The gateway to a broader neural focus on the brain in the study of stress began with the discovery in 1968 of putative receptors for adrenal steroids in the hippocampal formation. This 


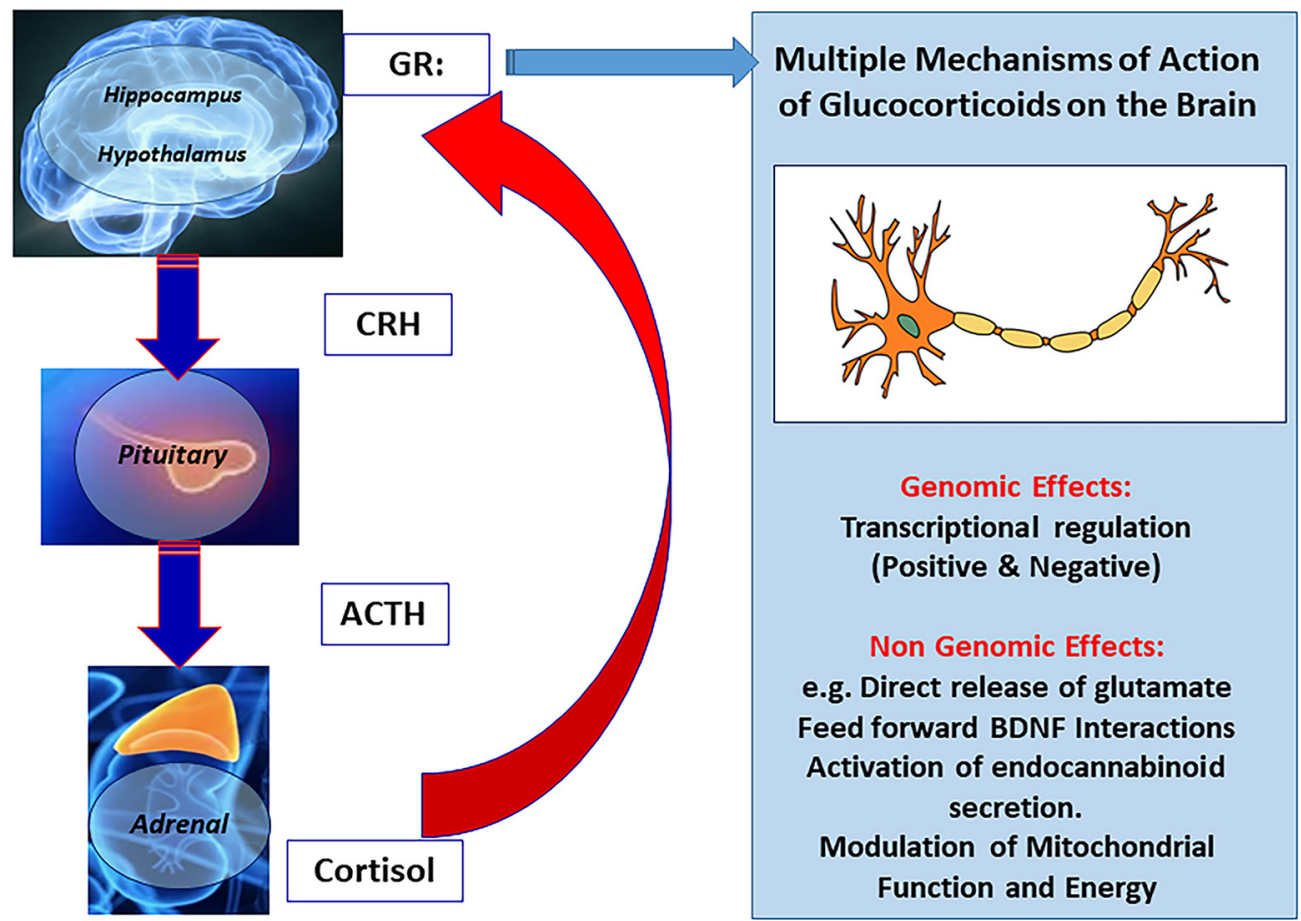

Figure 2. Key elements of the limbic HPA. Glucocorticoids feed back to the brain to restrain the stress response. They produce their actions via GRs and MRs, which are generally classified as ligand-dependent transcription factors that are expressed in multiple brain regions, especially the hippocampus. Glucocorticoid effects in the brain involve not only direct and indirect genomic actions, but also direct stimulation of glutamate release and stimulation of endocannabinoid production, which then feed back on glutamate and GABA release and actions in mitochondria to affect $\mathrm{Ca}^{2+}$ buffering and free radical formation. BDNF, in the presence of glucocorticoids, phosphorylates the GR at sites that facilitate its translocation to the cell nucleus for transcriptional actions; this effect is synergistic with the ability of glucocorticoids to promote the phosphorylation of the TrkB receptor independently of BDNF. Table 1 refers to mechanistic studies of mediators and cellular processes that are involved in the remodeling of neurons in hippocampus, amygdala, and prefrontal cortex.

work used ${ }^{3} \mathrm{H}$-corticosterone in adrenalectomized rats, and later in rhesus monkeys, to visualize the binding of this steroid hormone in the nervous system (McEwen et al., 1968). The discovery of these hippocampal glucocorticoid binding sites extended hormone action beyond the hypothalamus to a brain region that was already known to be involved in learning and memory, setting the stage for the much broader conceptualization summarized above. This presaged research that showed the brain to be the target of numerous other hormones, including sex, thyroid, and metabolic hormones, such as insulin and ghrelin (McEwen, 2007). However, $>25$ years would pass before the molecular nature of these glucocorticoid binding sites was identified.

It is now known that the impact of glucocorticoids on the brain (corticosterone in rodents and cortisol in humans) is mediated via two main receptors, the glucocorticoid receptor (GR) and the mineralocorticoid receptor (MR). Both are ligandactivated transcription factors (i.e., the binding of steroids modifies their transcriptional activity), leading to either positive or negative regulation of the expression of their target genes. The cloning of the GR took place in the early 1980s (Miesfeld et al., 1984; Hollenberg et al., 1985). This was followed shortly thereafter by the cloning of MR (Arriza et al., 1987). MR was subsequently cloned directly from a hippocampal library (Patel et al., 1989), and its anatomical expression in the brain was defined in direct comparison to GR, showing their close coexpression in many brain regions (Herman et al., 1989). MR has higher affinity for glucocorticoids than GR, and in the brain it functions coordinately with GR in the control of stress and its impact on affective and cognitive function (Joëls and de Kloet, 2017). While GR has been implicated in stress negative feedback, MR has been implicated in the modulation of basal glucocorticoid circadian rhythm and pulsatile secretion of ACTH into the blood (Bradbury et al., 1991; Gjerstad et al., 2018).

A healthy response to an acute stressor requires both a rapid and vigorous activation of a response that leads to the synthesis and release of glucocorticoids, as described above. But it also requires an effective means of terminating that stress response to avoid overwhelming the system with the powerful actions of the stress hormones. This termination is based on a negative feedback mechanism that is mediated at many levels-the pituitary, the PVN, and, especially, the hippocampus, which is rich in GR but in which the diurnal variation of glucocorticoids primes the system to turn off the HPA response rather than acting like a thermostat (Akana et al., 1988; Jacobson et al., 1988). The neural circuit that connects the hippocampus to the PVN and is critical for the termination of the stress response was first delineated by the laboratory of S. J. Watson (Cullinan et al., 1993; Herman et al., 1995). It involves a bisynaptic pathway from the hippocampus to the PVN with a relay station in the bed nucleus of the stria terminalis. Lesions along this pathway lead to overexpression of CRH mRNA in the PVN and long durations of the stress response. As will be described below, environmental and psychosocial factors that disrupt the hippocampus can also lead to excessive levels of glucocorticoids, which can in turn further damage the hippocampus.

\section{How brain and body systems continually interact for brain health and disease}

Identification of "stress hormone" receptors in hippocampus led in multiple other directions. In addition to hippocampus, such receptors were found to be expressed and act in other brain regions involved in cognition and emotion, such as amygdala and 
Table 1. Some molecules implicated in stress-related remodeling in hippocampus, amygdala, and prefrontal cortex

\begin{tabular}{|c|c|c|c|}
\hline General class & Molecule & Function & References \\
\hline \multirow[t]{7}{*}{ Secreted signaling molecules } & BDNF & Facilitates plasticity or growth & Chen et al., 2006; Govindarajan et al., 2006; \\
\hline & & Floor and ceiling effects & Bath et al., 2013 \\
\hline & FGF2 & $\begin{array}{l}\text { Facilitates neuroplasticity and neurogenesis in develop- } \\
\text { ment and adulthood }\end{array}$ & Perez et al., 2009 ; Turner et al, 2012 \\
\hline & $\mathrm{t}-\mathrm{PA}$ & $\begin{array}{l}\text { Mediates stress-induced spine loss in CA1 hippocampus } \\
\text { and medial amygdala } \\
\text { t-PA release regulated by CRF }\end{array}$ & $\begin{array}{l}\text { Pawlak et al., 2003, 2005; Matys et al., } \\
\text { 2004; Bennur et al., } 2007\end{array}$ \\
\hline & Lipocalin-2 secreted protein & $\begin{array}{l}\text { Induced by acute stress } \\
\text { Lipocalin-2 knockout increases neuronal excitability and } \\
\text { anxiety. }\end{array}$ & Mucha et al., 2011; Skrzypiec et al., 2013 \\
\hline & Endocannabinoids & $\begin{array}{l}\text { Induced via glucocorticoids } \\
\text { Regulate emotionality, HPA habituation and turn off } \\
\text { Buffer against stress induced remodeling }\end{array}$ & $\begin{array}{l}\text { Hill and McEwen, 2010; Hill et al., 2010, } \\
\text { 2013; Gunduz-Cinar et al., } 2013\end{array}$ \\
\hline & CRF after t-PA & $\begin{array}{l}\text { Stimulates rPA release; mediates plasticity of spine } \\
\text { synapses }\end{array}$ & Matys et al., 2004; Regev and Baram, 2014 \\
\hline \multirow[t]{3}{*}{$\begin{array}{l}\text { Cell surface and nucleo- cytoplasmic } \\
\text { interactions }\end{array}$} & PSA-NCAM & $\begin{array}{l}\text { Cell surface "anti-stickiness" } \\
\text { Endonuclease N removes PSA from NCAM; dendrite } \\
\text { expansion } \\
\text { Facilitate plasticity but also limits it }\end{array}$ & $\begin{array}{l}\text { Sandi, 2004; Rutishauser, 2008; McCall et } \\
\text { al., 2013; Nacher et al., } 2013\end{array}$ \\
\hline & Cell adhesion molecules & $\begin{array}{l}\text { Chronic stress disrupts neuroligin-neurexin interaction } \\
\text { Chronic stress reduces nectin-3 via MMP9 protease }\end{array}$ & van der Kooij et al., 2014a,b \\
\hline & NUP62 & $\begin{array}{l}\text { Reduction leads to dendrite shrinkage } \\
\text { Possibly due to nuclear-cytoplasmic communication }\end{array}$ & Kinoshita et al., 2014 \\
\hline
\end{tabular}

t-PA, Tissue plasminogen activator; PSA-NCAM, polysialic acid linked to neural cell adhesion molecule; rPA, raphe pallidus.

prefrontal cortex (Figs. 1,2), and acute and chronic stressors were found to cause adaptive structural plasticity within interconnected brain regions. Adaptive plasticity is a term that describes how chronic stress can remodel the brain in a neuroprotective manner, causing retraction of dendrites and loss of synapses in areas that are highly stress sensitive, such as hippocampus, medial amygdala, and medial prefrontal cortex, while at the same time causing the expansion of dendrites and new synapses in other areas such as basolateral amygdala and orbitofrontal cortex (Price and Drevets, 2010; McEwen and Morrison, 2013; Chattarji et al., 2015; Lau et al., 2017). These morphological changes subserve alterations in behavioral, autonomic, and neuroendocrine functions that are appropriate for coping with the ongoing stressor (e.g., ongoing threat or danger).

Based on animal models, numerous systemic and neural mediators contribute to adaptive plasticity, including insulin; IGF-1 from liver (Trejo et al., 2001); a muscle hormone, cathepsin B (Moon and van Praag, 2014); and the bone hormone osteocalcin (Khrimian et al., 2017), all of which gain access to the brain and act upon their respective receptors to induce protective morphological changes. Similarly, leptin, which is expressed in hippocampus but can also reach the hippocampus from the blood, facilitates neurogenesis and has antioxidant neuroprotective effects (Yook et al., 2019). Table 1 summarizes the range of mediators, including signaling molecules locally produced in brain, such as brain-derived neurotrophic factor (BDNF), FGF2 (fibroblast growth factor 2), endocannabinoids, and CRF, as well as cellular processes at the cell nucleus, cytoskeleton, and cell surface.

When conditions improve, the healthy brain exhibits resilience and recovers, even though this is not a true reversal, as some of the morphological changes persist and may even serve to buffer against further stress (Goldwater et al., 2009). However, if stressrelated demands continue, then the brain can "get stuck," that is, fail to further adapt structurally or functionally even when external stressors diminish, leading to pathological conditions where external intervention is needed (Figs. 1, 3). Examples of such conditions are clinical anxiety or major depression, which may begin with an appropriate response to a stressful event but become maladaptive when they persist and become chronic. Immune cells can gain access to a brain vulnerable to social stress (Menard et al., 2017), and the same mediators implicated in adaptive plasticity, including both glucocorticoids and excitatory amino acid transmitters, can cause permanent damage. This demonstrates the concept that there exists an inverted U-shaped function for optimal actions of glucocorticoids and other signaling molecules in response to stress (Fig. 3).

\section{Experience and the epigenetic life course}

The actions of hormones, and of experiences in general, result in epigenetic regulation of genetic information leading to individual differences even among identical twins. The epigenetic lifecourse perspective emphasizes that life is a one-way street where influences even before conception, as well as during prenatal development, childhood, adolescence, and onward determine trajectories of health or risk for disease. The idea of a continually unfolding activity of gene expression is exemplified in the pattern of hippocampal responses to stressors, wherein a given novel stressor produces some changes in gene expression that are shared across individuals, but also many changes that differ as a function of different histories of stress (Gray et al., 2014). While it is impossible to erase the biological consequences of experience, an individual's trajectory can be modified by additional experiences that can either enhance their ability to cope in a healthy manner or lead them to succumb to stress-related disorders. Such interventions can occur throughout life, but are particularly powerful during "windows of opportunity" such as fetal development, early childhood, and adolescence (Halfon et al., 2014). Understanding the molecular, cellular, and circuit mechanisms that underlie this dynamic process is a challenge for our field, and will require integration across levels of analysis. But it can begin with existing fundamental knowledge about "molecular organiz- 


\section{Biphasic Effects of Glucocorticoids: Impact on Synaptic Function and Neuroplasticity}

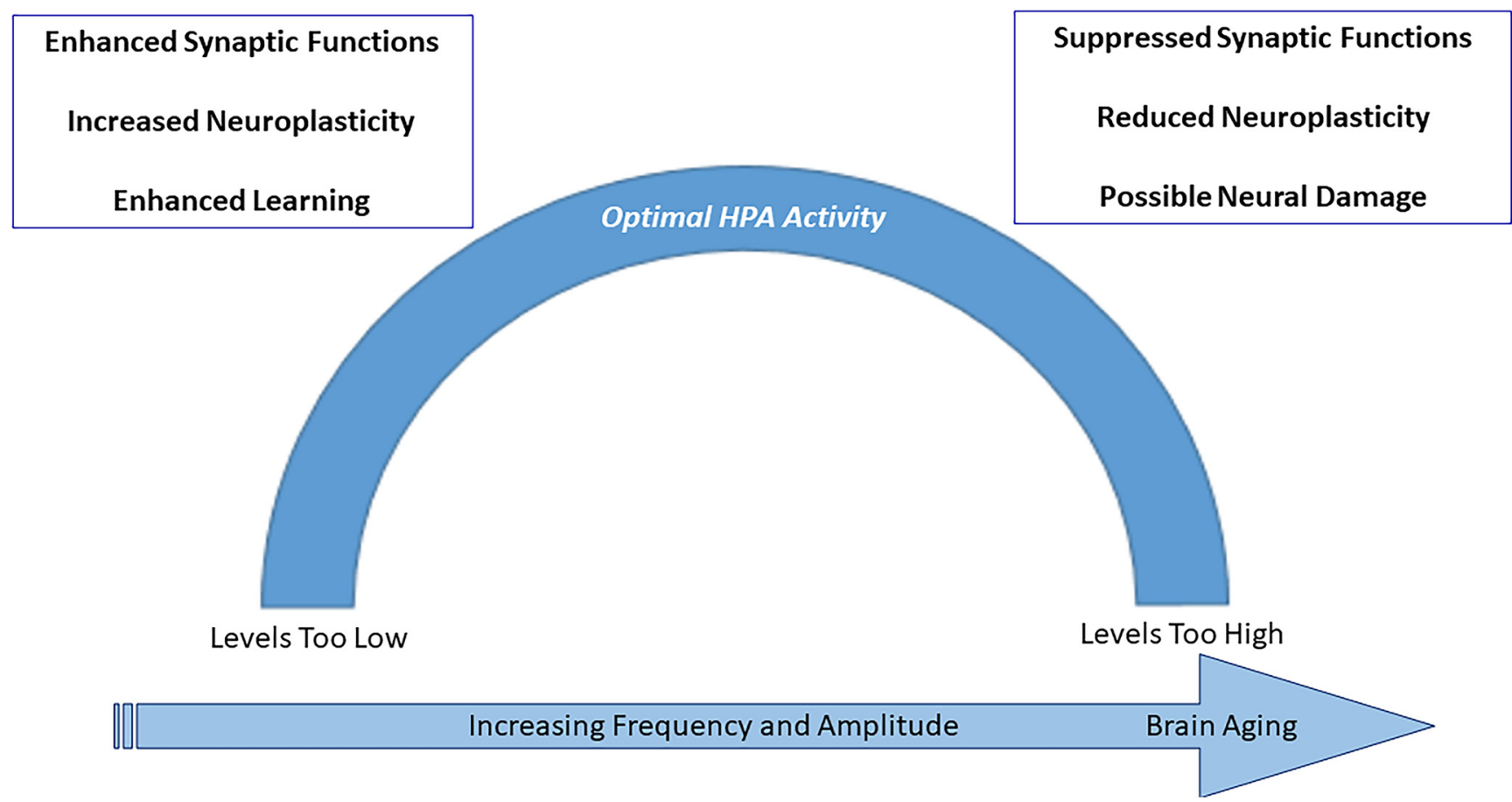

Figure 3. Glucocorticoids, excitatory amino acids and other mediators and processes noted in Table 1 operate in a nonlinear, biphasic manner to promote adaptive plasticity, on the one hand, and to impair resilience and promote damage, on the other hand. Lack of resilience in the aftermath of stressful experiences needs external intervention, as is the case for affective disorders.

ers" that play a key role in neurodevelopment and lifelong plasticity. Glucocorticoids and growth factors represent examples of such molecular organizers that impact development, gene expression, and the epigenetic impact of the environment on the biology of stress and coping.

\section{The central role of glucocorticoids and their receptors}

Steroid hormones were recognized in the 1960s as having major action via epigenetic regulation of gene expression. Upon their cloning, the corticosteroid hormone receptors GR and MR were classified as ligand-dependent transcription factors that reside preferentially in the cytoplasm as part of a complex of proteins. Interaction with glucocorticoid ligands causes the receptors to shuttle to the nucleus to modulate rates of transcription of target genes via a range of complex mechanisms that control gene expression, either enhancing or inhibiting it depending on the target genes and the presence of various molecular partners (Weikum et al., 2017). While this transcriptional modulation endows glucocorticoids with a broad, ranging impact on cellular function, researchers have uncovered additional (nontranscriptional) cellular and molecular mechanisms through which glucocorticoids, in conjunction with other mediators, affect processes from the nucleus to the cell surface, including mitochondria, causing structural remodeling of neurons. These discoveries reveal the complexity of glucocorticoid interactions both genomically and nongenomically (Fig. 2). These effects range from rapid actions related to the negative feedback mechanisms described above, to circadian modulatory actions, to lifelong organizing actions due to their ability to cause stable epigenetic modifications.

The wide-ranging importance of glucocorticoid receptors has been demonstrated by a range of genetic manipulations from knockout to overexpression to more targeted manipulations aimed specifically at the brain or at particular brain regions. Brain-wide knockout of GR results in significant endocrine imbalance, with elevated levels of corticosteroids and changes in energy metabolism and body weight control that are associated with changes in hormones such as leptin and insulin (Kellendonk et al., 2002). More targeted ablations of GR in specific circuits result in a range of behavioral and function changes, typically involving both neuroendocrine and affective functions (Whirledge and DeFranco, 2018).

The converse and somewhat less invasive intervention is to increase the expression of GR or MR only in certain regions and cell types in the brain to determine the associated molecular and behavioral phenotype. A series of studies examined the consequences of GR overexpression using a calcium/calmodulindependent protein kinase II $\alpha$ promoter that selects for forebrain glutamatergic neurons (Wei et al., 2004, 2007, 2012; HebdaBauer et al., 2010). The adult phenotype of the GRov mouse was striking in that the animals appear more prone to anxiety-like and depression-like behaviors, but the states were also highly labile-mice were more likely to switch affective state in response to even low levels of drugs, be they anti-depressant drugs or drugs of abuse, and they would swing readily to the other behavioral extreme (Wei et al., 2004; Hebda-Bauer et al., 2010). Most importantly, using an inducible, tissue-specific genetic induction, 
these studies showed that the GRov phenotype was fully established before weaning and associated with lifelong alterations in gene expression in the hippocampus, including in glutamatergic, GABAergic, and calcium regulatory pathways. Induction of GR overexpression after weaning and throughout the life of the animal yielded neither the altered affective responses nor the great lability in emotional reactivity (Wei et al., 2012). By contrast, MR overexpression, while less well studied, results in a distinctive phenotype with less anxiety behavior (Rozeboom et al., 2007), consonant with the view that the GR-MR balance is critical in many cellular and behavioral functions (Joëls and de Kloet, 2017). Experiments using current technologies such as optogenetic manipulations and CRISPR-Cas 9 are underway and should add further understanding to the role of these glucocorticoid receptors in ongoing regulation of affect and mood.

This body of genetic work along with research on the regulation of GR at the genomic, epigenetic, and gene expression levels establish this receptor as critical in the regulation of emotions and emotionality, not only basally but also in terms of dynamic reactivity to the environment, with social environment and early development playing a particularly powerful role (Turecki and Meaney, 2016).

\section{Stress and affective disorders: reverse translation to animal models}

Given the ongoing, powerful, and dynamic nature of stress biology described above, it is not surprising that dysregulation of the stress system and increased allostatic load are implicated in many psychiatric disorders. Indeed, affective disorders, including major depressive disorder (MDD), bipolar disorder, anxiety and panic disorders, and post-traumatic stress disorder (PTSD) can all be seen as stress disorders where key neural circuits that regulate stress reactivity are not functioning optimally. This dysregulation might include enhanced reactivity to threatening stimuli, decreased ability to terminate the stress response, and/or suboptimal coupling between internal affective states and external environment. This latter dysfunction can result in moods shifting in an extreme and seemingly random fashion in bipolar illness, or being "stuck" in a negative mode in major depression. Though heritable to various extents (ranging from 35\% for MDD to $>60 \%$ for bipolar disorder; Smoller and Finn, 2003; Geschwind and Flint, 2015), the nature of the vulnerability to these disorders relates to how the individual responds to the environment (Akil et al., 2018). Indeed, a recent major study on the genetics of depression (Wray et al., 2018) that examined $\sim 460,000$ subjects concludes that "All humans carry lesser or greater numbers of genetic risk factors for major depression" and notes that the findings are consistent with the dysregulation of the HPA axis in depression. How these genetic influences play out depends on the fine-tuning and plasticity of the stress response by the individual's developmental trajectory and life experiences.

While the brain plays a key role in orchestrating and finetuning stress responsiveness, it is important to recall that the brain is also the target of changes throughout the body, which are a major type of proximal, ongoing, and sometimes toxic stress. This includes metabolic syndrome and insulin resistance, which, like major depression, have become a global burden and are often comorbid with depression. The physiological mechanisms underlying this brain-body cross talk are receiving increasing attention (Watson et al., 2018), and the complex interplay between early life stressors and metabolic factors is being analyzed as one of the many paths to depressive illness (Nasca et al., 2019). Other physiological factors that influence how the brain responds to stress include increased circulating levels of $=$ glucocorticoids (e.g., in Cushing's disease), disrupted circadian rhythms, jet lag (Cho, 2001) and disrupted sleep, a sedentary life style, and others.

Demonstrating the impact of toxic stress and depression on the human brain has involved both structural and functional fMRI, which reveal shrinkage of the hippocampus. Postmortem human studies have not only confirmed the toxic effects of major depression on the brain but have also revealed the breadth and complexity of these neural perturbations at the molecular, cellular, and circuitry levels. This work is consistent with the presence of significant dysregulation in the stress circuitry, especially in the hippocampus (López et al., 1998; Webster et al., 2002; Klok et al., 2011; Medina et al., 2013). But it also reveals dynamic changes in many other functions important for motivational and affective functions. For example, the expression of circadian genes is highly disrupted in major depression, along with hundreds of other genes that are modulated in a circadian fashion. Thus, while the circadian expression signature of the control brain can pinpoint the time of death within an hour of its actual occurrence, the pattern in depressed brains is time shifted, making it impossible to match the circadian signature of the brain with the time of death (Li et al., 2013; Bunney et al., 2015). The widespread brain dysregulation revealed by these studies might be either the cause or the consequence of the disease process. Regardless, it likely contributes to the progressive disruption in physiology, affective and cognitive states, and behavioral functioning that are the hallmark of severe mood disorders.

Further underscoring the insidious nature of this stress disorder is the dysregulation of several gene families relating to cellular development, cell repair, and growth factors. For example, the FGF family was discovered to be dysregulated in major depression (Evans et al., 2004; Aurbach et al., 2015). Reverse translation studies reveal the close ties of this family not only to anxiety and depression behaviors, but also to the interplay with stress, emotional responsiveness, and vulnerability or resilience in response to life stressors.

In particular, a specific member of the FGF family, FGF2, has been shown to function as an "endogenous antidepressant." Hippocampal and frontal cortical levels of FGF2 are low in human depression, and they are also decreased in rodents following repeated social stress and have been shown to modulate the HPA axis via GR (Turner et al., 2008a,b, 2016; Salmaso et al., 2016). Exogenously administered FGF2 functions as an antidepressant in animal tests of depressive behavior, and neonatally administered FGF2 functions as a resilience factor, protecting animals against social defeat stress, enhancing extinction of learned fear, and decreasing anxiety behavior in animals genetically bred for high vulnerability to stress (Turner et al., 2008,b, 2011, 2012; Perez et al., 2009; Prater et al., 2017). In contrast, FGF9, which is elevated in depressed brain, functions as a vulnerability factor, which is increased by chronic stress in animal models (Aurbach et al., 2015), and its selective inhibition in the hippocampus diminishes anxiety behavior. Remarkably, resilience-inducing FGF2 treatment during early life results in epigenetic changes to GR in the hippocampus, increasing its association with a repressive histone, H3K9Me3 (Chaudhury et al., 2014), once again illustrating the role of both glucocorticoids and growth factors as organizing molecules that function during development in fine-tuning responsiveness to stress throughout the individual's life.

Overall, the combination of human neuroimaging studies and postmortem analyses reveals that stress-related affective disorders have a broader impact on the brain than we had previously estimated-they affect connectivity across multiple brain re- 
Table 2. Experience changes hippocampal volume

\begin{tabular}{|c|c|c|}
\hline & Cause & References \\
\hline \multirow[t]{9}{*}{ Hippocampal shrinkage } & Chronic stress & Gianaros et al., 2007a,b, 2008, 2014 \\
\hline & Major depression & Sheline et al., 2019 \\
\hline & PTSD & $\begin{array}{l}\text { Vythilingam et al., 2002; } \\
\text { Pitman et al., } 2006\end{array}$ \\
\hline & $\begin{array}{l}\text { Borderline personality } \\
\text { disorder }\end{array}$ & Driessen et al., 2000 \\
\hline & Cushing's disease & Starkman et al., 1992, 1999 \\
\hline & Dementia & de Leon et al., 1988 \\
\hline & Type 2 diabetes & Gold et al., 2007; Yau et al., 2012 \\
\hline & Chronic inflammation & Marsland et al., 2008 \\
\hline & Chronic jet lag & Cho, 2001 \\
\hline \multirow{2}{*}{$\begin{array}{l}\text { Hippocampal } \\
\text { enlargement }\end{array}$} & Exercise & Erickson et al., 2011 \\
\hline & Intense learning & Draganski et al., 2006 \\
\hline
\end{tabular}

The most extensive information about structural plasticity and damage in the human brain exists for hippocampus, but there is also increasing information about such changes in structure, activity and connectivity in human amygdala and prefrontal cortex. For example, the amygdala becomes more active and undergoes structural changes in mood disorders (Price and Drevets, 2010) and to threat in people of low socioeconomic (SES) standing (Gianaros et al., 2008), while low SES was associated with smaller gray matter volume in the dorsal anterior cingulate cortex, reduced myelin content and greater systemic preclinical atherosclerosis and IL-6 (Gianaros et al., 2007a,b, 2014). All of these conditions include increased frequency of mood disorders.

gions, and they impact multiple circuits, cell types, and molecular players. This is likely secondary to the unfolding of a lifelong process where mechanisms of adaptive neuroplasticity prove inadequate to compensate for the ongoing stress. This failure has neural and behavioral consequences, which in turn demand further and further efforts at adaptation and compensation, until these mechanisms fail, and this is expressed as a devastating disorder.

\section{Brain health and the broader social context}

The picture that emerges from neurobiological studies of depression, coupled with epidemiological analyses, highlights the interplay between stress biology and general health, which is strongly influenced by social context. This involves the whole life course, where poverty, as well as other forms of early life adversity such as abuse and neglect, increase disproportionately the risk for diabetes, depression, cardiovascular disease, substance abuse, and later dementia, and thus increase human misery and the health care cost burden (Shonkoff et al., 2009; McEwen and McEwen, 2017). Moreover, the hippocampus and interconnected brain regions such as amygdala and prefrontal cortex show effects accompanying these conditions on structure and function, examples of which are summarized in Table 2, illustrating the association between brain and body health.

The interplay between social context and stress biology brings us back to the broad concept of allostatic load, the impact of experience, and the concept of the "exposome" (Miller and Jones, 2014), which reflects how the totality of the social and physical environment shapes the brain and its ability to function both cognitively and affectively. The sum total of experiences can become restrictive and undermine optimal functioning (https:// macses.ucsf.edu/research/psychosocial/selfesteem.php). But by the same token, the ability to adapt, cope, and remodel the brain in an ongoing way also provides opportunities for positive change. Indeed, numerous studies have revealed the positive impact of activities such as regular exercise and intense learning in improving the volume and activity of the hippocampus and in mediating greater resilience to stress (Table 2).

\section{Future directions: the neurobiology of stress as the basic science of affective disorders}

Given the staggering burden of affective disorders, there is great interest in advancing our understanding of their underlying causes and translating this knowledge into better treatments. It is our view that the neurobiology of stress represents the basic biology of affective disorders. While we have accumulated an impressive body of knowledge in the last 50 years about stress biology, we have barely scratched the surface. For cancer research to make progress and begin to contemplate the possibility of precision medicine, it was essential to delve into the fundamental biology of cell growth, cell death, and cell signaling. In turn, the aberrations seen under pathological conditions of cancer pointed the way to new mechanisms and led to exciting fundamental discoveries. By the same token, it is essential that we achieve much greater depth, mechanistic understanding, and specificity in our field if we are to make a dent in the treatment and prevention of stress disorders. While the interest in precision medicine in neuroscience is high, the path remains unclear, as strongly predictive genetic markers and other biomarkers are not currently in hand. Confronting the heterogeneity of these diseases is a necessary first step. A better delineation of the many paths to affective disorders and how they might interface with different biological and clinical outcomes is essential.

This thinking should inform not only our human studies but also our attempts at animal models. In some cases, the mere recognition that the biology of stress matters in understanding the action of putative drugs is helpful (Fitzgerald et al., 2019). In other cases, more sophisticated tests need to be developed to account for the complex interplay of factors and experience in capturing key features of a particular subtype of affective illness and addressing it. Thus, a thoughtful and systematic approach to translation and reverse translation strategies is essential for making significant progress in treatment and prevention of stressrelated disorders (Bale et al., 2019).

In sum, our view of the biology of stress underscores its ongoing, cumulative, and adaptive nature. While this process can become dysregulated, leading to a range of affective, stress-related disorders, it also offers many opportunities for retuning, not only through medical approaches, but also through psychosocial strategies, as well as through a greater emphasis on general health and fitness as a means of achieving resilience. Focusing upon interventions to prevent or to ameliorate the effects of early life adversity can have a disproportionately large positive influence on individual and population health over the life course.

\section{References}

Akana SF, Jacobson L, Cascio CS, Shinsako J, Dallman MF (1988) Constant corticosterone replacement normalizes basal adrenocorticotropin (ACTH) but permits sustained ACTH hypersecretion after stress in adrenalectomized rats. Endocrinology 122:1337-1342.

Akil H, Watson SJ, Young E, Lewis ME, Khachaturian H, Walker JM (1984) Endogenous opioids: biology and function. Annu Rev Neurosci 7:223255.

Akil H, Gordon J, Hen R, Javitch J, Mayberg H, McEwen B, Meaney MJ, Nestler EJ (2018) Treatment resistant depression: a multi-scale, systems biology approach. Neurosci Biobehav Rev 84:272-288.

Arriza JL, Weinberger C, Cerelli G, Glaser TM, Handelin BL, Housman DE, Evans RM (1987) Cloning of human mineralocorticoid receptor complementary DNA: structural and functional kinship with the glucocorticoid receptor. Science 237:268-275.

Aurbach EL, Inui EG, Turner CA, Hagenauer MH, Prater KE, Li JZ, Absher D, Shah N, Blandino P Jr, Bunney WE, Myers RM, Barchas JD, Schatzberg AF, Watson SJ Jr, Akil H (2015) Fibroblast growth factor 9 is a novel modulator of negative affect. Proc Natl Acad Sci U S A 112:11953-11958. 
Bale TL, Abel T, Akil H, Carlezon WA Jr, Moghaddam B, Nestler EJ, Ressler KJ, Thompson SM (2019) The critical importance of basic animal research for neuropsychiatric disorders. Neuropsychopharmacology 44: 1349-1353.

Bath KG, Schilit A, Lee FS (2013) Stress effects on BDNF expression: effects of age, sex, and form of stress. Neuroscience 239:149-156.

Bennur S, Shankaranarayana Rao BS, Pawlak R, Strickland S, McEwen BS, Chattarji S (2007) Stress-induced spine loss in the medial amygdala is mediated by tissue-plasminogen activator. Neuroscience 144:8-16.

Bradbury MJ, Akana SF, Cascio CS, Levin N, Jacobson L, Dallman MF (1991) Regulation of basal ACTH secretion by corticosterone is mediated by both type I (MR) and type II (GR) receptors in rat brain. J Steroid Biochem Mol Biol 40:133-142.

Bunney BG, Li JZ, Walsh DM, Stein R, Vawter MP, Cartagena P, Barchas JD, Schatzberg AF, Myers RM, Watson SJ, Akil H, Bunney WE (2015) Circadian dysregulation of clock genes: clues to rapid treatments in major depressive disorder. Mol Psychiatry 20:48-55.

Chattarji S, Tomar A, Suvrathan A, Ghosh S, Rahman MM (2015) Neighborhood matters: divergent patterns of stress-induced plasticity across the brain. Nat Neurosci 18:1364-1375.

Chaudhury S, Aurbach EL, Sharma V, Blandino P Jr, Turner CA, Watson SJ, Akil H (2014) FGF2 is a target and a trigger of epigenetic mechanisms associated with differences in emotionality: partnership with H3K9me3. Proc Natl Acad Sci U S A 111:11834-11839.

Chen ZY, Jing D, Bath KG, Ieraci A, Khan T, Siao CJ, Herrera DG, Toth M, Yang C, McEwen BS, Hempstead BL, Lee FS (2006) Genetic variant BDNF (Val66Met) polymorphism alters anxiety-related behavior. Science 314:140-143.

Cho K (2001) Chronic "jet lag” produces temporal lobe atrophy and spatial cognitive deficits. Nat Neurosci 4:567-568.

Cullinan WE, Herman JP, Watson SJ (1993) Ventral subicular interaction with the hypothalamic paraventricular nucleus: evidence for a relay in the bed nucleus of the stria terminalis. J Comp Neurol 332:1-20.

de Leon MJ, McRae T, Tsai J, George A, Marcus D, Freedman M, Wolf AP, McEwen B (1988) Abnormal cortisol response in Alzheimer's disease linked to hippocampal atrophy. Lancet 2:391-392.

Draganski B, Gaser C, Kempermann G, Kuhn HG, Winkler J, Büchel C, May A (2006) Temporal and spatial dynamics of brain structure changes during extensive learning. J Neurosci 26:6314-6317.

Driessen M, Herrmann J, Stahl K, Zwaan M, Meier S, Hill A, Osterheider M, Petersen D (2000) Magnetic resonance imaging volumes of the hippocampus and the amygdala in women with borderline personality disorder and early traumatization. Arch Gen Psychiatry 57:1115-1122.

Erickson KI, Voss MW, Prakash RS, Basak C, Szabo A, Chaddock L, Kim JS, Heo S, Alves H, White SM, Wojcicki TR, Mailey E, Vieira VJ, Martin SA, Pence BD, Woods JA, McAuley E, Kramer AF (2011) Exercise training increases size of hippocampus and improves memory. Proc Natl Acad Sci U S A 108:3017-3022.

Evans SJ, Choudary PV, Neal CR, Li JZ, Vawter MP, Tomita H, Lopez JF, Thompson RC, Meng F, Stead JD, Walsh DM, Myers RM, Bunney WE, Watson SJ, Jones EG, Akil H (2004) Dysregulation of the fibroblast growth factor system in major depression. Proc Natl Acad Sci U S A 101: $15506-15511$.

Fitzgerald PJ, Yen JY, Watson BO (2019) Stress-sensitive antidepressantlike effects of ketamine in the mouse forced swim test. PLoS One 14: e0215554.

Gee CE, Chen CL, Roberts JL, Thompson R, Watson SJ (1983) Identification of proopiomelanocortin neurones in rat hypothalamus by in situ cDNA-mRNA hybridization. Nature 306:374-376.

Geschwind DH, Flint J (2015) Genetics and genomics of psychiatric disease. Science 349:1489-1494.

Gianaros PJ, Jennings JR, Sheu LK, Greer PJ, Kuller LH, Matthews KA (2007a) Prospective reports of chronic life stress predict decreased grey matter volume in the hippocampus. Neuroimage 35:795-803.

Gianaros PJ, Horenstein JA, Cohen S, Matthews KA, Brown SM, Flory JD, Critchley HD, Manuck SB, Hariri AR (2007b) Perigenual anterior cingulate morphology covaries with perceived social standing. Soc Cogn Affect Neurosci 2:161-173.

Gianaros PJ, Horenstein JA, Hariri AR, Sheu LK, Manuck SB, Matthews KA, Cohen S (2008) Potential neural embedding of parental social standing. Soc Cogn Affect Neurosci 3:91-96.

Gianaros PJ, Marsland AL, Kuan DC, Schirda BL, Jennings JR, Sheu LK,
Hariri AR, Gross JJ, Manuck SB (2014) An inflammatory pathway links atherosclerotic cardiovascular disease risk to neural activity evoked by the cognitive regulation of emotion. Biol Psychiatry 75:738-745.

Gjerstad JK, Lightman SL, Spiga F (2018) Role of glucocorticoid negative feedback in the regulation of HPA axis pulsatility. Stress 21:403-416.

Gold SM, Dziobek I, Sweat V, Tirsi A, Rogers K, Bruehl H, Tsui W, Richardson S, Javier E, Convit A (2007) Hippocampal damage and memory impairments as possible early brain complications of type 2 diabetes. Diabetologia 50:711-719.

Goldwater DS, Pavlides C, Hunter RG, Bloss EB, Hof PR, McEwen BS, Morrison JH (2009) Structural and functional alterations to rat medial prefrontal cortex following chronic restraint stress and recovery. Neuroscience 164:798-808.

Govindarajan A, Rao BS, Nair D, Trinh M, Mawjee N, Tonegawa S, Chattarji $S$ (2006) Transgenic brain-derived neurotrophic factor expression causes both anxiogenic and antidepressant effects. Proc Natl Acad Sci U S A 103:13208-13213.

Gray JD, Rubin TG, Hunter RG, McEwen BS (2014) Hippocampal gene expression changes underlying stress sensitization and recovery. Mol Psychiatry 19:1171-1178.

Gunduz-Cinar O, Hill MN, McEwen BS, Holmes A (2013) Amygdala FAAH and anandamide: mediating protection and recovery from stress. Trends Pharmacol Sci 34:637-644.

Halfon N, Larson K, Lu M, Tullis E, Russ S (2014) Lifecourse health development: past, present and future. Matern Child Health J 18:344-365.

Hebda-Bauer EK, Pletsch A, Darwish H, Fentress H, Simmons TA, Wei Q, Watson SJ, Akil H (2010) Forebrain glucocorticoid receptor overexpression increases environmental reactivity and produces a stressinduced spatial discrimination deficit. Neuroscience 169:645-653.

Herman JP, Patel PD, Akil H, Watson SJ (1989) Localization and regulation of glucocorticoid and mineralocorticoid receptor messenger RNAs in the hippocampal formation of the rat. Mol Endocrinol 3:1886-1894.

Herman JP, Cullinan WE, Morano MI, Akil H, Watson SJ (1995) Contribution of the ventral subiculum to inhibitory regulation of the hypothalamo-pituitary-adrenocortical axis. J Neuroendocrinol 7:475-482.

Hill MN, McEwen BS (2010) Involvement of the endocannabinoid system in the neurobehavioural effects of stress and glucocorticoids. Prog Neuropsychopharmacol Biol Psychiatry 34:791-797.

Hill MN, McLaughlin RJ, Bingham B, Shrestha L, Lee TT, Gray JM, Hillard CJ, Gorzalka BB, Viau V (2010) Endogenous cannabinoid signaling is essential for stress adaptation. Proc Natl Acad Sci U S A 107:9406-9411.

Hill MN, Kumar SA, Filipski SB, Iverson M, Stuhr KL, Keith JM, Cravatt BF, Hillard CJ, Chattarji S, McEwen BS (2013) Disruption of fatty acid amide hydrolase activity prevents the effects of chronic stress on anxiety and amygdalar microstructure. Mol Psychiatry 18:1125-1135.

Hollenberg SM, Weinberger C, Ong ES, Cerelli G, Oro A, Lebo R, Thompson EB, Rosenfeld MG, Evans RM (1985) Primary structure and expression of a functional human glucocorticoid receptor cDNA. Nature 318:635641.

Jacobson L, Akana SF, Cascio CS, Shinsako J, Dallman MF (1988) Circadian variations in plasma corticosterone permit normal termination of adrenocorticotropin responses to stress. Endocrinology 122:1343-1348.

Joëls M, de Kloet ER (2017) 30 years of the mineralocorticoid receptor: the brain mineralocorticoid receptor: a saga in three episodes. J Endocrinol 234:T49-T66.

Kellendonk C, Eiden S, Kretz O, Schütz G, Schmidt I, Tronche F, Simon E (2002) Inactivation of the GR in the nervous system affects energy accumulation. Endocrinology 143:2333-2340.

Khrimian L, Obri A, Ramos-Brossier M, Rousseaud A, Moriceau S, Nicot AS, Mera P, Kosmidis S, Karnavas T, Saudou F, Gao XB, Oury F, Kandel E, Karsenty G (2017) Gpr158 mediates osteocalcin's regulation of cognition. J Exp Med 214:2859-2873.

Kinoshita Y, Hunter RG, Gray JD, Mesias R, McEwen BS, Benson DL, Kohtz DS (2014) Role for NUP62 depletion and PYK2 redistribution in dendritic retraction resulting from chronic stress. Proc Natl Acad Sci U S A 111:16130-16135.

Klok MD, Alt SR, Irurzun Lafitte AJ, Turner JD, Lakke EA, Huitinga I, Muller CP, Zitman FG, de Kloet ER, Derijk RH (2011) Decreased expression of mineralocorticoid receptor mRNA and its splice variants in postmortem brain regions of patients with major depressive disorder. J Psychiatr Res 45:871-878.

Lau T, Bigio B, Zelli D, McEwen BS, Nasca C (2017) Stress-induced struc- 
tural plasticity of medial amygdala stellate neurons and rapid prevention by a candidate antidepressant. Mol Psychiatry 22:227-234.

Li CH, Simpson ME, Evans HM (1942) Isolation of adrenocorticotropic hormone from sheep pituitaries. Science 96:450.

Li CH, Geschwind II, Cole RD, Raacke ID, Harris JI, Dixon JS (1955) Amino-acid sequence of alpha-corticotropin. Nature 176:687-689.

Li JZ, Bunney BG, Meng F, Hagenauer MH, Walsh DM, Vawter MP, Evans SJ, Choudary PV, Cartagena P, Barchas JD, Schatzberg AF, Jones EG, Myers RM, Watson SJ Jr, Akil H, Bunney WE (2013) Circadian patterns of gene expression in the human brain and disruption in major depressive disorder. Proc Natl Acad Sci U S A 110:9950-9955.

López JF, Chalmers DT, Little KY, Watson SJ (1998) AE. bennett research award. regulation of serotonin1A, glucocorticoid, and mineralocorticoid receptor in rat and human hippocampus: implications for the neurobiology of depression. Biol Psychiatry 43:547-573.

Mains RE, Eipper BA, Ling N (1977) Common precursor to corticotropins and endorphins. Proc Natl Acad Sci U S A 74:3014-3018.

Marsland AL, Gianaros PJ, Abramowitch SM, Manuck SB, Hariri AR (2008) Interleukin-6 covaries inversely with hippocampal grey matter volume in middle-aged adults. Biol Psychiatry 64:484-490.

Matys T, Pawlak R, Matys E, Pavlides C, McEwen BS, Strickland S (2004) Tissue plasminogen activator promotes the effects of corticotropin releasing factor on the amygdala and anxiety-like behavior. Proc Natl Acad Sci U S A 101:16345-16350.

McCall T, Weil ZM, Nacher J, Bloss EB, El Maarouf A, Rutishauser U, McEwen BS (2013) Depletion of polysialic acid from neural cell adhesion molecule (PSA-NCAM) increases CA3 dendritic arborization and increases vulnerability to excitotoxicity. Exp Neurol 241:5-12.

McEwen BS (1998) Protective and damaging effects of stress mediators. N Engl J Med 338:171-179.

McEwen BS (2000) Allostasis and allostatic load: implications for neuropsychopharmacology. Neuropsychopharmacology 22:108-124.

McEwen BS (2007) Physiology and neurobiology of stress and adaptation: central role of the brain. Physiol Rev 87:873-904.

McEwen BS (2019) What is the confusion with cortisol? Chronic Stress (Thousand Oaks) 3:1-3.

McEwen BS, Morrison JH (2013) The brain on stress: vulnerability and plasticity of the prefrontal cortex over the life course. Neuron 79:16-29.

McEwen BS, Weiss JM, Schwartz LS (1968) Selective retention of corticosterone by limbic structures in rat brain. Nature 220:911-912.

McEwen CA, McEwen BS (2017) Social structure, adversity, toxic stress, and intergenerational poverty: an early childhood model. Annu Rev Sociol 43:445-472.

Medina A, Seasholtz AF, Sharma V, Burke S, Bunney W Jr, Myers RM, Schatzberg A, Akil H, Watson SJ (2013) Glucocorticoid and mineralocorticoid receptor expression in the human hippocampus in major depressive disorder. J Psychiatr Res 47:307-314.

Menard C, Pfau ML, Hodes GE, Kana V, Wang VX, Bouchard S, Takahashi A, Flanigan ME, Aleyasin H, LeClair KB, Janssen WG, Labonté B, Parise EM, Lorsch ZS, Golden SA, Heshmati M, Tamminga C, Turecki G, Campbell M, Fayad ZA, et al. (2017) Social stress induces neurovascular pathology promoting depression. Nat Neurosci 20:1752-1760.

Miesfeld R, Okret S, Wikström AC, Wrange O, Gustafsson JA, Yamamoto KR (1984) Characterization of a steroid hormone receptor gene and mRNA in wild-type and mutant cells. Nature 312:779-781.

Miller GW, Jones DP (2014) The nature of nurture: refining the definition of the exposome. Toxicol Sci 137:1-2.

Moon HY, van Praag H (2014) Muscle over mind. Cell Metab 20:560-562.

Mucha M, Skrzypiec AE, Schiavon E, Attwood BK, Kucerova E, Pawlak R (2011) Lipocalin-2 controls neuronal excitability and anxiety by regulating dendritic spine formation and maturation. Proc Natl Acad Sci U S A 108:18436-18441.

Nacher J, Guirado R, Castillo-Gómez E (2013) Structural plasticity of interneurons in the adult brain: role of PSA-NCAM and implications for psychiatric disorders. Neurochem Res 38:1122-1133.

Nakanishi S, Inoue A, Kita T, Nakamura M, Chang AC, Cohen SN, Numa S (1979) Nucleotide sequence of cloned cDNA for bovine corticotropinbeta-lipotropin precursor. Nature 278:423-427.

Nasca C, Watson-Lin K, Bigio B, Robakis TK, Myoraku A, Wroolie TE, McEwen BS, Rasgon N (2019) Childhood trauma and insulin resistance in patients suffering from depressive disorders. Exp Neurol 315:15-20.

Patel PD, Sherman TG, Goldman DJ, Watson SJ (1989) Molecular cloning of a mineralocorticoid (type I) receptor complementary DNA from rat hippocampus. Mol Endocrinol 3:1877-1885.

Pawlak R, Magarinos AM, Melchor J, McEwen B, Strickland S (2003) Tissue plasminogen activator in the amygdala is critical for stress-induced anxiety-like behavior. Nat Neurosci 6:168-174.

Pawlak R, Rao BS, Melchor JP, Chattarji S, McEwen B, Strickland S (2005) Tissue plasminogen activator and plasminogen mediate stress-induced decline of neuronal and cognitive functions in the mouse hippocampus. Proc Natl Acad Sci U S A 102:18201-18206.

Perez JA, Clinton SM, Turner CA, Watson SJ, Akil H (2009) A new role for FGF2 as an endogenous inhibitor of anxiety. J Neurosci 29:6379-6387.

Pitman RK, Gilbertson MW, Gurvits TV, May FS, Lasko NB, Metzger LJ, Shenton ME, Yehuda R, Orr SP (2006) Clarifying the origin of biological abnormalities in PTSD through the study of identical twins discordant for combat exposure. Ann NY Acad Sci 1071:242-254.

Prater KE, Aurbach EL, Larcinese HK, Smith TN, Turner CA, Blandino P Jr, Watson SJ, Maren S, Akil H (2017) Selectively bred rats provide a unique model of vulnerability to PTSD-like behavior and respond differentially to FGF2 augmentation early in life. Neuropsychopharmacology 42:1706-1714.

Price JL, Drevets WC (2010) Neurocircuitry of mood disorders. Neuropsychopharmacology 35:192-216.

Regev L, Baram TZ (2014) Corticotropin releasing factor in neuroplasticity. Front Neuroendocrinol 35:171-179.

Roberts JL, Herbert E (1977) Characterization of a common precursor to corticotropin and beta-lipotropin: cell-free synthesis of the precursor and identification of corticotropin peptides in the molecule. Proc Natl Acad Sci U S A 74:4826-4830.

Rozeboom AM, Akil H, Seasholtz AF (2007) Mineralocorticoid receptor overexpression in forebrain decreases anxiety-like behavior and alters the stress response in mice. Proc Natl Acad Sci U S A 104:4688-4693.

Rutishauser U (2008) Polysialic acid in the plasticity of the developing and adult vertebrate nervous system. Nat Rev Neurosci 9:26-35.

Salmaso N, Stevens HE, McNeill J, ElSayed M, Ren Q, Maragnoli ME, Schwartz ML, Tomasi S, Sapolsky RM, Duman R, Vaccarino FM (2016) Fibroblast growth factor 2 modulates hypothalamic pituitary axis activity and anxiety behavior through glucocorticoid receptors. Biol Psychiatry 80:479-489.

Sandi C (2004) Stress, cognitive impairment and cell adhesion molecules. Nat Rev Neurosci 5:917-930.

Schally, AV, Andersen RN, Lipscomb HS, Long JM, Guillemin R (1960) Evidence for the existence of two corticotrophin-releasing factors, alpha and beta. Nature 188:192-193.

Sheline YI, Liston C, McEwen BS (2019) Parsing the hippocampus in depression: chronic stress, hippocampal volume, and major depressive disorder. Biol Psychiatry 85:436-438.

Shonkoff JP, Boyce WT, McEwen BS (2009) Neuroscience, molecular biology, and the childhood roots of health disparities. JAMA 301:2252-2259.

Skrzypiec AE, Shah RS, Schiavon E, Baker E, Skene N, Pawlak R, Mucha M (2013) Stress-induced lipocalin-2 controls dendritic spine formation and neuronal activity in the amygdala. PLoS One 8:e61046.

Smoller JW, Finn CT (2003) Family, twin, and adoption studies of bipolar disorder. Am J Med Genet C Semin Med Genet 123C:48-58.

Spencer-Segal JL, Akil H (2019) Glucocorticoids and resilience. Horm Behav 111:131-134.

Starkman MN, Gebarski SS, Berent S, Schteingart DE (1992) Hippocampal formation volume, memory dysfunction, and cortisol levels in partiens with Cushing's syndrome. Biol Psychiatry 32:756-765.

Starkman MN, Giordani B, Gebarski SS, Berent S, Schork MA, Schteingart DE (1999) Decrease in cortisol reverses human hippocampal atrophy following treatment of Cushing's disease. Biol Psychiatry 46:15951602.

Trejo JL, Carro E, Torres-Aleman I (2001) Circulating insulin-like growth factor I mediates exercise-induced increases in the number of new neurons in the adult hippocampus. J Neurosci 21:1628-1634.

Turecki G, Meaney MJ (2016) Effects of the social environment and stress on glucocorticoid receptor gene methylation: a systematic review. Biol Psychiatry 79:87-96.

Turner CA, Calvo N, Frost DO, Akil H, Watson SJ (2008a) The fibroblast growth factor system is downregulated following social defeat. Neurosci Lett 430:147-150. 
Turner CA, Gula EL, Taylor LP, Watson SJ, Akil H (2008b) Antidepressantlike effects of intracerebroventricular FGF2 in rats. Brain Res 1224:63-68.

Turner CA, Clinton SM, Thompson RC, Watson SJ Jr, Akil H (2011) Fibroblast growth factor-2 (FGF2) augmentation early in life alters hippocampal development and rescues the anxiety phenotype in vulnerable animals. Proc Natl Acad Sci U S A 108:8021-8025.

Turner CA, Watson SJ, Akil H (2012) The fibroblast growth factor family: neuromodulation of affective behavior. Neuron 76:160-174.

Turner CA, Watson SJ, Akil H (2016) Fibroblast growth factor 2 sits at the interface of stress and anxiety. Biol Psychiatry 80:419-421.

Vale W, Spiess J, Rivier C, Rivier J (1981) Characterization of a 41-residue ovine hypothalamic peptide that stimulates secretion of corticotropin and beta-endorphin. Science 213:1394-1397.

van der Kooij MA, Fantin M, Kraev I, Korshunova I, Grosse J, Zanoletti O, Guirado R, Garcia-Mompó C, Nacher J, Stewart MG, Berezin V, Sandi C (2014a) Impaired hippocampal neuroligin-2 function by chronic stress or synthetic peptide treatment is linked to social deficits and increased aggression. Neuropsychopharmacology 39:1148-1158.

van der Kooij MA, Fantin M, Rejmak E, Grosse J, Zanoletti O, Fournier C, Ganguly K, Kalita K, Kaczmarek L, Sandi C (2014b) Role for MMP-9 in stress-induced downregulation of nectin-3 in hippocampal CA1 and associated behavioural alterations. Nat Commun 5:4995.

Vythilingam M, Luckenbaugh DA, Lam T, Morgan CA, Lipschitz D, Charney DS, Bremner JD, Southwick SM (2005) Smaller head of the hippocampus in Gulf War-related posttraumatic stress disorder. Psychiatry Res 139:89-99.

Watson K, Nasca C, Aasly L, McEwen B, Rasgon N (2018) Insulin resistance, an unmasked culprit in depressive disorders: promises for interventions. Neuropharmacology 136:327-334.

Webster MJ, Knable MB, O'Grady J, Orthmann J, Weickert CS (2002) Regional specificity of brain glucocorticoid receptor mRNA alterations in subjects with schizophrenia and mood disorders. Mol Psychiatry 7:985-994.
Wei Q, Lu XY, Liu L, Schafer G, Shieh KR, Burke S, Robinson TE, Watson SJ, Seasholtz AF, Akil H (2004) Glucocorticoid receptor overexpression in forebrain: a mouse model of increased emotional lability. Proc Natl Acad Sci U S A 101:11851-11856.

Wei Q, Hebda-Bauer EK, Pletsch A, Luo J, Hoversten MT, Osetek AJ, Evans SJ, Watson SJ, Seasholtz AF, Akil H (2007) Overexpressing the glucocorticoid receptor in forebrain causes an aging-like neuroendocrine phenotype and mild cognitive dysfunction. J Neurosci 27:8836-8844.

Wei Q, Fentress HM, Hoversten MT, Zhang L, Hebda-Bauer EK, Watson SJ, Seasholtz AF, Akil H (2012) Early-life forebrain glucocorticoid receptor overexpression increases anxiety behavior and cocaine sensitization. Biol Psychiatry 71:224-231.

Weikum ER, Knuesel MT, Ortlund EA, Yamamoto KR (2017) Glucocorticoid receptor control of transcription: precision and plasticity via allostery. Nat Rev Mol Cell Biol 18:159-174.

Whirledge S, DeFranco DB (2018) Glucocorticoid signaling in health and disease: insights from tissue-specific GR knockout mice. Endocrinology 159:46-64.

Wray NR, Ripke S, Mattheisen M, Trzaskowski M, Byrne EM, Abdellaoui A, Adams MJ, Agerbo E, Air TM, Andlauer TMF, Bacanu SA, BækvadHansen M, Beekman AFT, Bigdeli TB, Binder EB, Blackwood DRH, Bryois J, Buttenschøn HN, Bybjerg-Grauholm J, Cai N, et al. (2018) Genome-wide association analyses identify 44 risk variants and refine the genetic architecture of major depression. Nat Genet 50:668-681.

Yau PL, Castro MG, Tagani A, Tsui WH, Convit A (2012) Obesity and metabolic syndrome and functional and structural brain impairments in adolescence. Pediatrics 130:e856-e864

Yook JS, Rakwal R, Shibato J, Takahashi K, Koizumi H, Shima T, Ikemoto MJ, Oharomari LK, McEwen BS, Soya H (2019) Leptin in hippocampus mediates benefits of mild exercise by an antioxidant on neurogenesis and memory. Proc Natl Acad Sci U S A 116:10988-10993. 